\title{
Reactive oxygen system plays an important role in shrimp Litopenaeus vannamei defense against Vibrio parahaemolyticus and WSSV infection
}

\author{
Pei-Feng Ji, Cui-Luan Yao*, Zhi-Yong Wang \\ Key Laboratory of Science and Technology for Aquaculture and Food Safety of Fujian Province University, \\ Fisheries College/Fisheries Biotechnology Institute, Jimei University, Xiamen, 361021, PR China
}

\begin{abstract}
The present study investigated the in vivo hemocytic and hepatopancreatic response to Vibrio parahaemolyticus and white spot syndrome virus (WSSV) injection in shrimp Litopenaeus vannamei. The proliferation of bacteria and virus in shrimp, animal mortality, total hemocyte counts (THCs), phenoloxidase (PO) activity, respiratory burst, and gene expression of immune factors associated with immune recognition (lectin), prophenoloxidase (proPO) activation, and the anti-microorganism (lysozyme) and active oxygen defense response (including respiratory burst, cytosolic manganese superoxide dismutase [C-MnSOD], and catalase [CAT]) were quantified. Shrimp death rate increased significantly and was time-dependent after $V$. parahaemolyticus or WSSV injection. The production of superoxide anion, and the gene expression including lectin in hemocytes, proPO in the hepatopancreas, lysozyme, C-MnSOD and CAT could be induced by injection with $V$. parahaemolyticus and WSSV. The highest value of lysozyme was in the hemocytes with 66.59 times (at $3 \mathrm{~h}$ ) greater expression than in the control group after WSSV injection and 3.69 times $(24 \mathrm{~h})$ greater than in the control group after $V$. parahaemolyticus injection. In the hepatopancreas, CAT expression showed a significant increase, with up to 16 times greater expression than in the control group at $6 \mathrm{~h}$ postinjection with WSSV and 7.02 times greater expression than in the control group at $48 \mathrm{~h}$ postinjection with $V$. parahaemolyticus $(\mathrm{p}<0.05)$. However, significant decreases in PO activity and proPO transcripts in hemocytes and lectin transcripts in the hepatopancreas were detected after $V$. parahaemolyticus and WSSV injection $(\mathrm{p}<0.05)$. The results suggest that lysozyme, the antioxidase system, and reactive oxygen species might play a crucial role in shrimp defense against bacterial and viral infection.
\end{abstract}

KEY WORDS: Litopenaeus vannamei - Vibrio parahaemolyticus - White spot syndrome virus · WSSV · Lectin · Prophenoloxidase system · proPO system · Lysozyme · Reactive oxygen species system $\cdot$ ROS system

\section{INTRODUCTION}

Shrimp, like other invertebrates, do not have acquired immunity. Instead, they have developed an innate immune system to avoid being consumed by hostile microorganisms (Loker et al. 2004). This innate immune system consists mainly of a non-self-microorganism recognition system, a prophenoloxidase (proPO) activating system, a phagocytosis, encapsulation and clotting system, and a bactericide system, including the synthesis and release of antibacterial peptides and reactive oxygen compounds.

The innate immune system of shrimp can be triggered by pathogens and mediated by the pattern recognition proteins (PRPs) (Janeway \& Medzhitov 2002). Therefore, recognizing non-self material that has gained entrance into the body is considered to be the first and essential step. C-type lectin is one of the PRPs of the innate immune system of invertebrates, and it plays an important role by serving as a PRP or 
opsonin in shrimp defense against bacteria and virus infection (Liu et al. 2007, Sun et al. 2008). However, the current understanding of lectin involvement in crustacean non-self recognition and immune response is limited. The proPO system is a key immune response pathway involved in the immune defense of invertebrates, leading to melanin production, cell adhesion, encapsulation, and phagocytosis (Söderhäll et al. 1998, Sritunyalucksana et al. 2000). Its activation involves a complex enzymatic cascade system which consists of many associated factors. Recently, some researches have focused on the variation in phenoloxidase (PO) activity and proPO transcripts in hemocytes during the shrimp immune response (Sritunyalucksana et al. 2000, Okumura 2007). However, the details of the relationships between the proPO system and other immune factors in the shrimp anti-bacterial and antiviral immune response are not clear.

The anti-bacterial and anti-viral responses play an extremely important role in shrimp. Lysozyme catalyzes the hydrolysis of bacterial cell walls and acts as a non-specific innate immunity molecule preventing the invasion of bacterial pathogens in eukaryotes and prokaryotes (Jollès \& Jollès 1984). Recently, some studies have shown that the shrimp lysozyme displays lytic activity against several Vibrio species and white spot syndrome virus (WSSV) (Hikima et al. 2003, Zhao et al. 2007, Yao et al. 2008). The activated innate immune system also engages in phagocytosis to eliminate invading microorganisms. During this process, microbicidal reactive oxygen species (ROS), such as superoxide anion $\left(\mathrm{O}_{2}{ }^{-}\right)$, hydrogen peroxide $\left(\mathrm{H}_{2} \mathrm{O}_{2}\right)$, hydroxide ions $\left(\mathrm{OH}^{-}\right)$, and singlet oxygen $\left(\mathrm{O}_{2} \cdot\right)$ and reactive oxygen intermediates (ROI) are produced and need to be eliminated promptly with the aid of the antioxidant enzymes such as superoxide dismutases (SOD) and catalase (CAT) found in virtually all oxygen-respiring organisms (Holmblad \& Söderhäll 1999, Devasagayam et al. 2004, Yao et al. 2004, 2007). These can destroy foreign invaders efficiently if directed at the right target.

Many pathogens that affect the sustainable development of the shrimp culture industry, including viral, bacterial and fungal species, have been identified (Lightner \& Redman 1998). Among the shrimp viral pathogens, WSSV is highly pathogenic and responsible for a huge economic loss in the shrimp industry worldwide (Chang et al. 1998). Disease outbreak has also been reported to be associated with an increase in Vibrio populations in cultured pond water. Vibriosis has been implicated as the major cause of mortality in juvenile penaeid shrimp (Lightner \& Redman 1998, Sung et al. 2001).

Our previous work has shown that the shrimp immune response has a complex course and is corre- lated with many factors in different pathways (Yao et al. 2005, 2009, 2010, Ji et al. 2009). Several important immune factors and genes of the Pacific white shrimp Litopenaeus vannamei have been studied. However, the relationships among the recognition system, the proPO system, and the non-oxidative and oxidative antibacterial system in shrimp after stimulation with Vibrio species and WSSV are poorly understood. In this study, we infected L. vannamei with Vibrio parahaemolyticus and WSSV, and investigated bacterial and viral proliferation, animal mortality, and the shrimp immune response, including total hemocyte counts (THCs), PO activity, superoxide anion production and the expression of the immune-related genes C-type lectin, proPO, lysozyme, cytosolic Mn superoxide dismutase (C-MnSOD) and CAT in the hemocytes and hepatopancreas.

\section{MATERIALS AND METHODS}

Experimental shrimps. Healthy cultured shrimp Litopenaeus vannamei (weight $12.5 \pm 3.6 \mathrm{~g}$, length $11.2 \pm 1.4 \mathrm{~cm}$ ) were sampled from Xiamen, China, and acclimated for at least $2 \mathrm{~d}$ in $2 \mathrm{~m}^{3}$ tanks in salinity $(18 \%)$, temperature $\left(24^{\circ} \mathrm{C}\right)$, and density $\left(2\right.$ shrimps $\left.\mathrm{l}^{-1}\right)$ conditions similar to those of the culture ponds from which the specimens were obtained. Shrimps were selected randomly for PCR analysis to detect Vibrio parahaemolyticus and WSSV. No sexual distinction was made and only intermolt individuals were used in this study.

Experimental pathogens. Vibrio parahaemolyticus $\left(G^{-}\right)$was isolated from diseased Pacific white shrimp and cultured in media $(1 \%$ peptone, $0.3 \%$ yeast extract, $2 \% \mathrm{NaCl}_{1} \mathrm{pH} 7.2$ ) at $28^{\circ} \mathrm{C}$ for $24 \mathrm{~h}$ before use. WSSV was obtained from WSSV-infected shrimp and was kindly supplied by Dr. Xiaobo Zhang.

Immune challenge and sample collection. Shrimp immune challenge was performed by intramuscularly injecting $50 \mu \mathrm{l}$ Vibrio parahaemolyticus or WSSV suspension in physiological saline solution (La Peyre \& Chu 1990) into the last abdominal segment of each shrimp at a concentration of $2 \times 10^{8} \mathrm{CFU} \mathrm{ml}{ }^{-1}$ or $10^{5}$ copies $\mathrm{ml}^{-1}$, respectively (shrimp lethal dose, $\mathrm{LD}_{50}$, at $48 \mathrm{~h}$ ). Shrimp injected with $50 \mu \mathrm{l}$ sterile physiological saline solution were maintained as controls. Six shrimp were used for each group, and each treatment was composed of 3 replicates of 6 shrimp. Hemolymph was collected from the ventral sinus, diluted 1:2 in precooled sterile shrimp anti-coagulant as described by Vargas-Albores et al. (1998). Hemocytes were isolated by centrifugation at $800 \times g, 4^{\circ} \mathrm{C}$, for $5 \mathrm{~min}$ and preserved immediately in liquid nitrogen. At the same time, the hepatopancreas was dissected out and pre- 
served in liquid nitrogen for RNA extraction. Hemocytes and hepatopancreas were collected from each group at $3,6,12,24$, and $48 \mathrm{~h}$ after injection, and preserved for biochemical assay and real-time reverse transcription polymerase chain reaction (RT-PCR).

Hemocyte lysate supernatant (HLS) preparation. HLS was prepared using modified techniques (Smith \& Söderhäll 1991). The diluted hemolymph $(0.6 \mathrm{ml})$ was centrifuged at $800 \times g$ for $10 \mathrm{~min}$ at $4^{\circ} \mathrm{C}$, the cell pellet was rinsed, re-suspended gently in $0.6 \mathrm{ml}$ ice cold cacodylate-citrate buffer $(10 \mathrm{mM}$ sodium cacodylate,

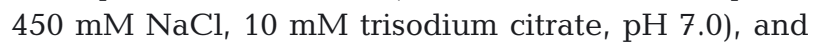
then centrifuged again. The pellet was then resuspended in $0.6 \mathrm{ml}$ ice cold cacodylate (CAC) buffer (10 mM sodium cacodylate, $450 \mathrm{mM} \mathrm{NaCl}, 10 \mathrm{mM}$ $\mathrm{CaCl}_{2}, 260 \mathrm{mM} \mathrm{MgCl}$, pH 7.0). This suspension was homogenized with a sonicator equipped with a microtip (10 W $\times 5 \mathrm{~s}, 5$ times with $20 \mathrm{~s}$ intervals) and centrifuged at $15000 \times g$ for $20 \mathrm{~min}$ at $4^{\circ} \mathrm{C}$. The supernatants were adjusted to similar protein concentrations and stored at $-80^{\circ} \mathrm{C}$ as HLS preparations. Protein content in the HLS was measured via the Bradford (1976) method, using bovine serum albumin as a standard protein.

Vibrio parahaemolyticus and WSSV proliferation, and shrimp mortality. Samples were prepared according to the method described by Yang et al. (1997). Briefly, $20 \mu \mathrm{g}$ shrimp muscle was homogenized in
$500 \mu \mathrm{l}$ of guanidine lysis buffer $(50 \mathrm{mM}$ Tris- $\mathrm{HCl}$, $\mathrm{pH}$ 8.0, 25 mM EDTA, 4 M guanidinium thiocyanate, $0.5 \% \mathrm{~N}$-lauroylsarcosine) at room temperature. After centrifugation at $15000 \times g$ for $3 \mathrm{~min}, 20 \mu \mathrm{l}$ silica were added to the supernatant for DNA absorption. Subsequently, the mixture was rotated for $5 \mathrm{~min}$, followed by centrifugation at $15000 \times g$ for $30 \mathrm{~s}$. The pellet was rinsed twice with $70 \%$ ethanol and resuspended in $20 \mu \mathrm{l}$ distilled water. Then it was centrifuged at $15000 \times g$ for $2 \mathrm{~min}$. The DNA sample was used at a concentration of $50 \mathrm{ng}^{-1} \mathrm{l}^{-1}$ as a PCR template to detect pathogen proliferation, and $\beta$-actin was used as an internal reference ( $\beta$-actin-2 primers, Table 1 ).

For detection of Vibrio parahaemolyticus, PCR was performed using 2 Vibrio-specific primers targeting the tox $R$ gene (Table 1 ), with 1 cycle of denaturation at $94^{\circ} \mathrm{C}$ for $3 \mathrm{~min}, 40 \mathrm{cycles}$ at $94^{\circ} \mathrm{C}$ for $30 \mathrm{~s}, 54^{\circ} \mathrm{C}$ for $30 \mathrm{~s}$ and $72^{\circ} \mathrm{C}$ for $30 \mathrm{~s}$, followed by a $10 \mathrm{~min}$ extension at $72^{\circ} \mathrm{C}$. For WSSV detection, PCR was performed using 2 WSSV thymidine kinase primers (Table 1 ) with 1 cycle of denaturation at $94^{\circ} \mathrm{C}$ for $3 \mathrm{~min}, 40$ cycles at $94^{\circ} \mathrm{C}$ for $30 \mathrm{~s}, 68^{\circ} \mathrm{C}$ for $30 \mathrm{~s}$ and $72^{\circ} \mathrm{C}$ for $30 \mathrm{~s}$, followed by a $10 \mathrm{~min}$ extension at $72^{\circ} \mathrm{C}$ (Xu et al. 2007).

Shrimp mortality was evaluated by calculating the number of dead shrimp after intramuscular injection of a $50 \mu \mathrm{l}$ suspension of Vibrio parahaemolyticus or WSSV. Ten shrimp were used for each group, and each treatment was carried out in triplicate.

Table 1. Primers used for detection of Vibrio parahaemolyticus and white spot syndrome virus (WSSV), and quantitative real-time PCR analysis of immune-related genes of the Pacific white shrimp Litopenaeus vannamei. C-MnSOD: cytosolic manganase superoxide dismutase; CAT: catalase

\begin{tabular}{|c|c|c|c|c|}
\hline Target gene & Forward/reverse sequence & $\begin{array}{l}\text { Product } \\
\text { size (bp) }\end{array}$ & GenBank no. & Source \\
\hline$V \cdot$ parahaemolyticus tox $R$ & $\begin{array}{l}\text { 5'-GTC TTC TGA CGC AAT CGT TG-3' } \\
\text { 5'- ATA CGA GTG GTT GCT GTC ATG-3' }\end{array}$ & 368 & EU155599.1 & Kim et al. (1999) \\
\hline WSSV thymidine kinase & $\begin{array}{l}\text { 5'-TAT TGT CTC TCC TGA CGT AC-3' } \\
\text { 5'-CAC ATT CTT CAC GAG TCT AC-3' }\end{array}$ & 300 & AF132668.1 & Xu et al. (2007) \\
\hline Lectin & $\begin{array}{l}\text { 5'-TCA GAA CTG CCT TGC GAT CAC-3' } \\
\text { 5'-CAC GCC ATT TGC TCA TCC A-3' }\end{array}$ & 109 & DQ871245 & Ma et al. (2007) \\
\hline Prophenoloxidase & $\begin{array}{l}\text { 5'-CGG TGA CAA AGT TCC TCT TC-3' } \\
\text { 5'-GCA GGT CGC CGT AGT AAG-3' }\end{array}$ & 122 & AY723296 & Wang et al. (2007) \\
\hline Lysozyme & $\begin{array}{l}\text { 5'-TTC CGA TCT GAT GTC CGA TGA-3' } \\
\text { 5'-TTG CTG TTG TAA GCC ACC CAG-3' }\end{array}$ & 123 & AY170126 & \\
\hline C-MnSOD & $\begin{array}{l}\text { 5'-GCT ACA TTA ACA ACC TAA TTG C-3 } \\
\text { 5'-ATG TTG GTC CAG AAG ATG GTG T-3 }\end{array}$ & 143 & DQ005531 & $\begin{array}{l}\text { Gómez-Anduro et al. } \\
\text { (2006) }\end{array}$ \\
\hline CAT & $\begin{array}{l}\text { 5'-CAA GTG GCG ATT ACC CCT CAT-3' } \\
\text { 5'-CCC ATG AGG CCA TAC TTT GGT-3' }\end{array}$ & 110 & AY518322 & $\begin{array}{l}\text { Tavares-Sánchez et al. } \\
\text { (2004) }\end{array}$ \\
\hline$\beta$-actin & $\begin{array}{l}\text { 5'-CCA CGA GAC CAC CTA CAA C-3' } \\
\text { 5'-AGC GAG GGC AGT GAT TTC-3' }\end{array}$ & 142 & AF300705 & Sun et al. (2007) \\
\hline$\beta$-actin-2 & $\begin{array}{l}\text { 5'-AGT AGC CGC CCT GGT TGT AGA C-3' } \\
5^{\prime} \text {-TTC TCC ATG TCG TCC CAG T-3' }\end{array}$ & 240 & AF300705 & Sun et al. (2007) \\
\hline
\end{tabular}


THCs. Samples of $100 \mu$ diluted hemolymph were fixed with an equal volume of $10 \%$ formaldehyde for 30 min at $4^{\circ} \mathrm{C}$. A drop of the 2 columns hemolymph suspension was placed on a hemocytometer, and THCs were carried out using a light microscope (Olympus).

PO activity assay and respiratory burst activity. PO activity in HLS was measured according to the method described previously (Söderhäll \& Unestam 1979, Smith \& Söderhäll 1991) and using L-DOPA (L-3,4dihydroxyphenylalanine, Sigma) as substrate and trypsin (Sigma, cat. no. T0646) as activator. Briefly, $200 \mu \mathrm{l}$ HLS was incubated with $200 \mu \mathrm{l} 0.1 \%$ trypsin in CAC buffer at room temperature for $30 \mathrm{~min}$, and then $200 \mu \mathrm{l} 0.3 \%$ L-DOPA in CAC buffer was added. Each reaction mixture was further diluted with $600 \mu \mathrm{l}$ CAC buffer and mixed, and the optical density was measured at $490 \mathrm{~nm}$. Absorbance measurements were made against a blank consisting of CAC buffer, LDOPA and trypsin to control for spontaneous oxidation of the substrate alone. One unit of enzyme activity was defined as an increase in absorbance of $0.001 \mathrm{~min}^{-1}$ $\mathrm{mg}^{-1}$ protein.

Superoxide anion detection. Superoxide anion was quantified by the method of Muñoz et al. (2000). Briefly, a determined number of hemocytes (about $5 \times$ $10^{5}$ ) collected from 6 shrimp were deposited in triplicate in $100 \mu \mathrm{l}$ final volume of medium in wells of a 96-well microtiterplate (Corning Costar 3599) and incubated in humid conditions for $30 \mathrm{~min}$ at room temperature to allow adherence of the hemocytes. The supernatants were then removed and replaced with $100 \mathrm{\mu l} \mathrm{CM}$ solution $\left(2.63 \% \mathrm{NaCl}_{1} 0.042 \% \mathrm{KCl}, 0.006 \%\right.$ $\mathrm{NaH}_{2} \mathrm{PO}_{4} \cdot 2 \mathrm{H}_{2} \mathrm{O}, 0.32 \% \mathrm{MgSO}_{4} \cdot 7 \mathrm{H}_{2} \mathrm{O}, 0.074 \% \mathrm{CaCl}_{2}$ - $2 \mathrm{H}_{2} \mathrm{O}, 0.03 \%$ L-glutamine, $\mathrm{pH} 7.45$ ). Then, $50 \mu \mathrm{l} 0.3 \%$ nitroblue tetrazolium (NBT) working solution in the appropriate medium were immediately distributed to the wells. Following a $2 \mathrm{~h}$ incubation, the supernatants were removed and the hemocytes were fixed by the addition of $200 \mu \mathrm{l}$ absolute methanol, washed twice with $70 \%$ methanol, then dried. The formazan deposits were solubilized in $120 \mu \mathrm{l} 2 \mathrm{M} \mathrm{KOH}$ and $140 \mu \mathrm{l}$ DMSO. After homogenization of the contents in the wells, the extinction was read at $620 \mathrm{~nm}$ in a Synergy HT MultiDetection Microplate Reader.

Total RNA isolation and cDNA synthesis. Total RNA was extracted from hemocytes and hepatopancreas with TriPure Isolation Reagent (Roche) following the manufacturer's protocol, and the RNA was treated with RQ1 RNase-Free DNase (Promega) to remove the contaminating DNA. First strand cDNA was synthesized from total RNA by ReverAidTM M-MuLV Reverse Transcriptase (Fermentas) with oligo(dT)18 primer following the manufacturer's protocol.

Quantitative real-time RT-PCR (qRT-PCR) analysis of gene expression. Expression of the 5 target genes (lectin, proPO, lysozyme, C-MnSOD, catalase) and the internal control ( $\beta$-actin) were measured by qRT-PCR. Primers of each gene were designed based on published Litopenaeus vannamei cDNA using the Primer Express 2.0 software (ABI) (Table 1). cDNA reverse transcribed from hemocytes and hepatopancreas was used as the template for analyzing the expression of the target genes. All PCR products were cloned into the pMD18-T vector (TaKaRa) and sequenced by Invitrogen (Shanghai).

Real-time RT-PCR was carried out in an ABI 7500 Real-time Detection System (Applied Biosystems) using a protocol described previously (Ji et al. 2009). Dissociation analysis of amplification products was performed at the end of each PCR reaction to confirm that only 1 PCR product was amplified and detected. cDNA from each target tissue of the 6 experimental shrimp was used for analysis. Each sample was run in duplicate for each gene, using the shrimp $\beta$-actin gene as the internal control. A negative control reaction was included for each primer set by omitting the template cDNA. After the PCR reaction, data were analyzed with the ABI 7500 SDS software (Applied Biosystems). To maintain consistency, the baseline was set automatically by the software. The comparative threshold cycle (CT) method $\left(2^{-\Delta \Delta C T}\right.$ method) was used to analyze the expression level of the target gene (Livak \& Schmittgen 2001). All data were given in terms of relative mRNA expressed as mean \pm SE. The data was subjected to $t$-test analysis, and p-values smaller than 0.05 were considered statistically significant.

Statistical analysis. A multiple comparison (Tukey's honestly significant difference, HSD) test was performed to examine the significant differences among treatments using the SPSS 15.0 software (SPSS). Percent data (susceptibility test) were normalized using an arcsine transformation before analysis. Differences were considered statistically significant when $\mathrm{p}<0.05$. The results of 1-way ANOVA were plotted using Origin 8.0 software (OriginLab).

\section{RESULTS}

\section{Vibrio parahaemolyticus and WSSV proliferation and shrimp mortality rate detection}

A 368 bp segment of the tox $R$ gene from Vibrio parahaemolyticus and a $300 \mathrm{bp}$ segment of the thymidine kinase gene from WSSV were obtained and sequenced. The proliferation of both pathogens showed a remarkable time-dependent increase after injection (Fig. 1). The results showed that $56.7 \pm 15.3 \%$ and $46.7 \pm 5.8 \%$ shrimp died after $V$. parahaemolyticus and WSSV injection, respectively (Table 2). The mortality 

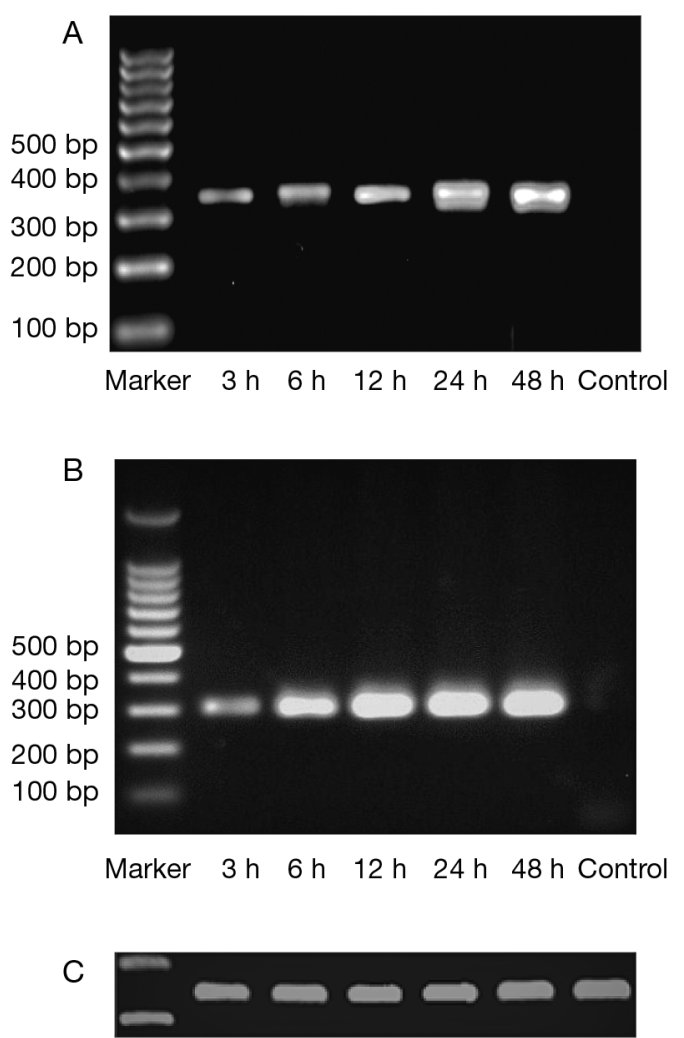

Fig. 1. Litopenaeus vannamei. PCR detection of (A) Vibrio parahaemolyticus and (B) WSSV proliferation from muscle DNA after pathogen challenge. (C) $\beta$-actin gene used as internal standard

of shrimp injected with $V$. parahaemolyticus or WSSV was significantly higher than that of the control group at 24 and $48 \mathrm{~h}$.

\section{Non-specific immunity parameters of shrimp}

THCs showed a significant decrease after Vibrio parahaemolyticus and WSSV injection (Fig. 2). They

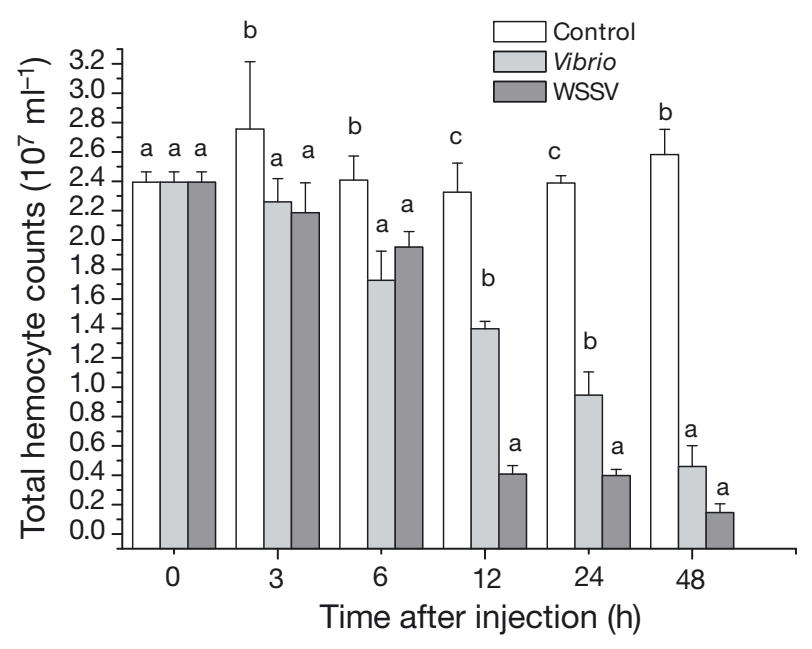

Fig. 2. Litopenaeus vannamei. Circulating (mean \pm SE) total hemocyte counts (THCs) at 3, 6, 12, 24, and $48 \mathrm{~h}$ after injection with shrimp physiological saline, or Vibrio parahaemolyticus $\left(1 \times 10^{7} \mathrm{CFU}\right)$ or WSSV $\left(10^{5}\right.$ copies $\left.\mathrm{ml}^{-1}\right)$ in shrimp physiological saline. Different letters indicate significant differences $(p<0.05)$ among treatments at the same point post-injection. ( $\mathrm{n}=6$ for each group, in triplicate)

gradually decreased from 3 to $48 \mathrm{~h}$ post-injection, with the lowest point appearing at $48 \mathrm{~h}(\mathrm{p}<0.05)$. From 12 to $48 \mathrm{~h}$, the THCs were much lower in the WSSVinjected group than in the $V$. parahaemolyticusinjected group. In the control group, the THCs of the shrimp did not change significantly.

Following treatment with Vibrio parahaemolyticus and WSSV, PO activity in shrimp hemocytes showed significant changes (Fig. 3A). It dropped significantly following injection with $V$. parahaemolyticus, reaching a value of $36.7 \%$ of the control group value at $6 \mathrm{~h}$ postinjection ( $\mathrm{p}<0.05)$, and then it showed fluctuating recovery. However, after WSSV injection, the lowest activity $(16.4 \%$ of the control group value) was reached at $48 \mathrm{~h}$. PO activity in the control group did not show any significant change. In the hepatopancreas (Fig. 3B), PO activity increased from 3 to $6 \mathrm{~h}$ after $V$.

Table 2. Litopenaeus vannamei. Cumulative mortality (\%) and number of dead shrimp in each group (in parentheses) and for each treatment during $48 \mathrm{~h}$ after injection with Vibrio parahaemolyticus or WSSV. Data in the challenge groups in the same row with different letters are significantly different $(p<0.05)$. Values are mean $\pm S E(n=10$ shrimp in each group, in triplicate)

\begin{tabular}{|c|c|c|c|c|c|}
\hline Treatment & $3 \mathrm{~h}$ & $6 \mathrm{~h}$ & $12 \mathrm{~h}$ & $24 \mathrm{~h}$ & $48 \mathrm{~h}$ \\
\hline Physiological saline solution & $\begin{array}{c}0 \\
(0,0,0)\end{array}$ & $\begin{array}{c}3.3 \pm 5.8^{\mathrm{a}} \\
(1,0,0)\end{array}$ & $\begin{array}{l}3.3 \pm 5.8^{\mathrm{a}} \\
(1,0,0)\end{array}$ & $\begin{array}{l}3.3 \pm 5.8^{\mathrm{a}} \\
(1,0,0)\end{array}$ & $\begin{array}{l}3.3 \pm 5.8^{\mathrm{a}} \\
(1,0,0)\end{array}$ \\
\hline V. parahaemolyticus & $\begin{array}{c}0^{\mathrm{a}} \\
(0,0,0)\end{array}$ & $\begin{array}{c}3.3 \pm 5.8^{\mathrm{a}} \\
(1,0,0)\end{array}$ & $\begin{array}{l}30 \pm 10^{b} \\
(4,2,3)\end{array}$ & $\begin{array}{c}46.7 \pm 5.8^{\mathrm{b}} \\
(5,4,5)\end{array}$ & $\begin{array}{c}56.7 \pm 15^{\mathrm{b}} \\
(7,4,6)\end{array}$ \\
\hline WSSV & $\begin{array}{c}0^{\mathrm{a}} \\
(0,0,0)\end{array}$ & $\begin{array}{c}3.3 \pm 5.8^{\mathrm{a}} \\
(1,0,0)\end{array}$ & $\begin{array}{l}10 \pm 0^{\mathrm{a}} \\
(1,1,1)\end{array}$ & $\begin{array}{c}33.3 \pm 5.8^{\mathrm{b}} \\
(3,3,4)\end{array}$ & $\begin{array}{c}46.7 \pm 5.8^{\mathrm{b}} \\
(5,4,5)\end{array}$ \\
\hline
\end{tabular}




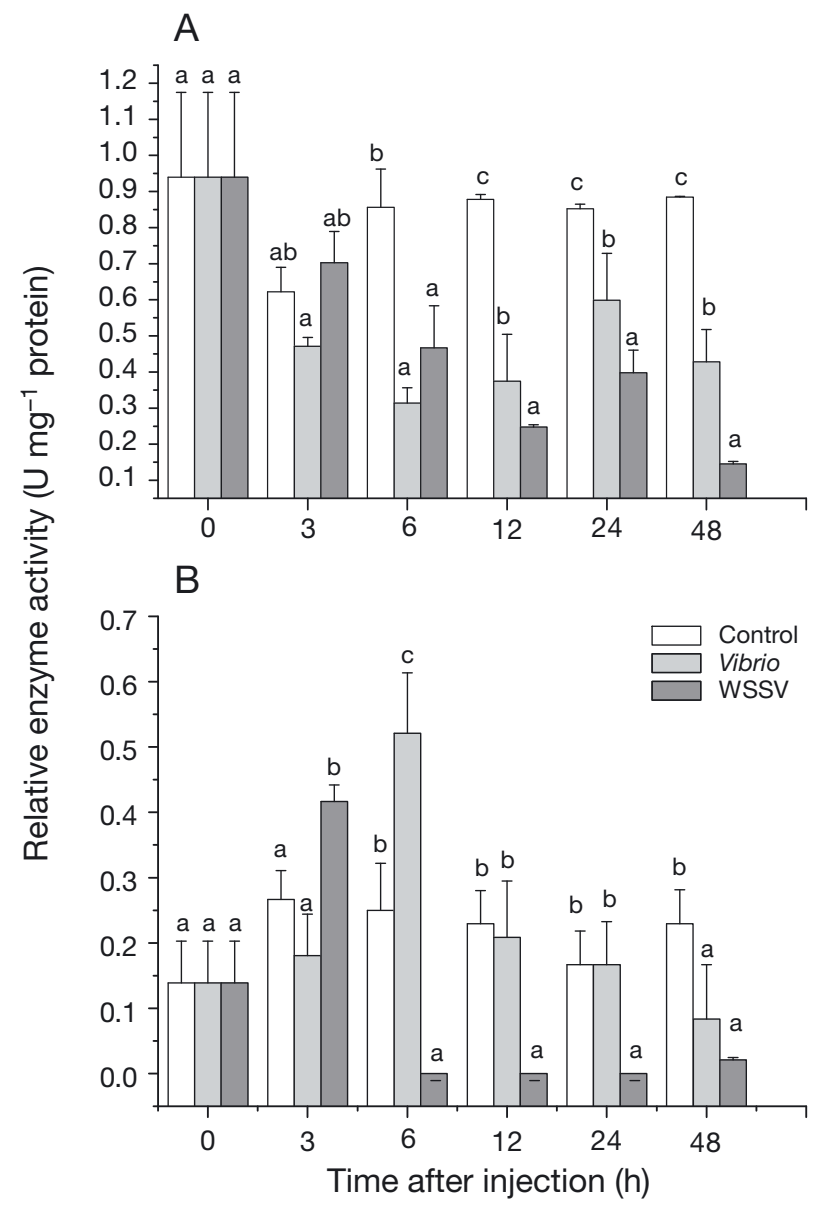

Fig. 3. Litopenaeus vannamei. Changes (mean $\pm \mathrm{SE}$ ) in phenoloxidase (PO) activity in (A) hemocytes and (B) the hepatopancreas at $0,3,6,12,24$ and $48 \mathrm{~h}$ after injection with Vibrio parahaemolyticus or WSSV. Shrimp physiological saline was injected as a mock induction. Different letters indicate significant differences $(p<0.05)$ among treatments at the same time point post-injection

parahaemolyticus injection, with a peak value of 2.1 times as high as that of the control group. It then decreased gradually and was lower than that of the control group at $48 \mathrm{~h}$ post-injection $(\mathrm{p}<0.05)$. In the WSSV injection group, PO activity increased significantly at first, with a peak of 1.6 times higher than that of the control group at $3 \mathrm{~h}$ after injection $(\mathrm{p}<0.05)$. However, it decreased sharply at $6 \mathrm{~h}(\mathrm{p}<0.05)$, and maintained a low level up to $48 \mathrm{~h}$ after injection.

The superoxide anion production in shrimp hemocytes increased significantly after injection with Vibrio parahaemolyticus and WSSV (Fig. 4). The highest value appeared at $3 \mathrm{~h}$ after WSSV injection, and was 2.7 times as high as that of the control group $(p<0.05)$. A high level was maintained up to $48 \mathrm{~h}$ after injection. Superoxide anion production in the control group did not show notable variation.

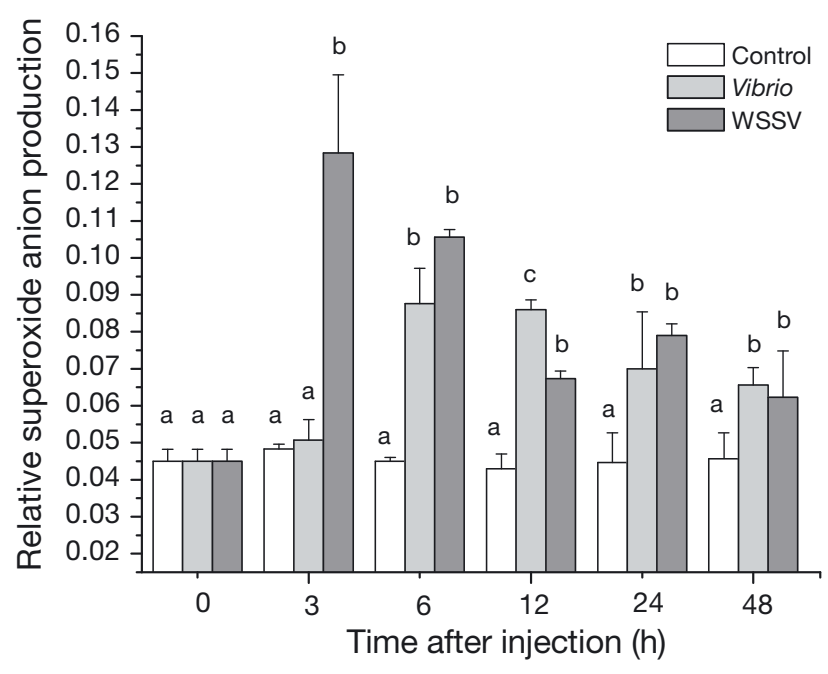

Fig. 4. Litopenaeus vannamei. Changes (mean $\pm \mathrm{SE}$ ) in superoxide anion production in hemocytes after injection with Vibrio parahaemolyticus or WSSV at $0,3,6,12,24$ and $48 \mathrm{~h}$. Shrimp physiological saline was injected as a mock induction. Different letters indicate significant differences $(p<0.05)$ among treatments at the same time point post-injection

\section{Expression profiles of immune-related genes}

Expression profiles of the lectin gene in hemocytes and the hepatopancreas after Vibrio parahaemolyticus and WSSV injection are shown in Fig. 5. In hemocytes, the level of lectin transcripts dropped at $3 \mathrm{~h}$ and remained at a low level up to $12 \mathrm{~h}$ after injection with $V$. parahaemolyticus $(\mathrm{p}<0.05)$. However, it increased dramatically at $24 \mathrm{~h}$ and reached a peak at $48 \mathrm{~h}$ postinjection, with a value 3.9 times higher than that of the control group. After WSSV injection, the lectin expression level only increased significantly at $24 \mathrm{~h}$. However, in the hepatopancreas, the level of lectin transcripts dropped sharply at $3 \mathrm{~h}$ post-injection $(\mathrm{p}<0.05)$ and maintained a low level up to $48 \mathrm{~h}$ after injection with $V$. parahaemolyticus and WSSV. The expression of lectin transcripts in the control group did not show significant variation post-injection.

Expression profiles of the proPO gene in hemocytes and the hepatopancreas after Vibrio parahaemolyticus and WSSV injection are shown in Fig. 6. In hemocytes (Fig. 6A), a significant decrease in proPO expression $(\mathrm{p}<0.05)$ was observed from 3 to $48 \mathrm{~h}$ after injection with $V$. parahaemolyticus and WSSV. However, in the hepatopancreas (Fig. 6B), the proPO expression levels increased at $48 \mathrm{~h}$ post-injection with both bacteria and virus $(\mathrm{p}<0.05)$.

Expression profiles of the lysozyme gene in hemocytes and hepatopancreas after Vibrio parahaemolyticus and WSSV injection are shown in Fig. 7. In hemocytes, the level of lysozyme transcripts showed a sharp 


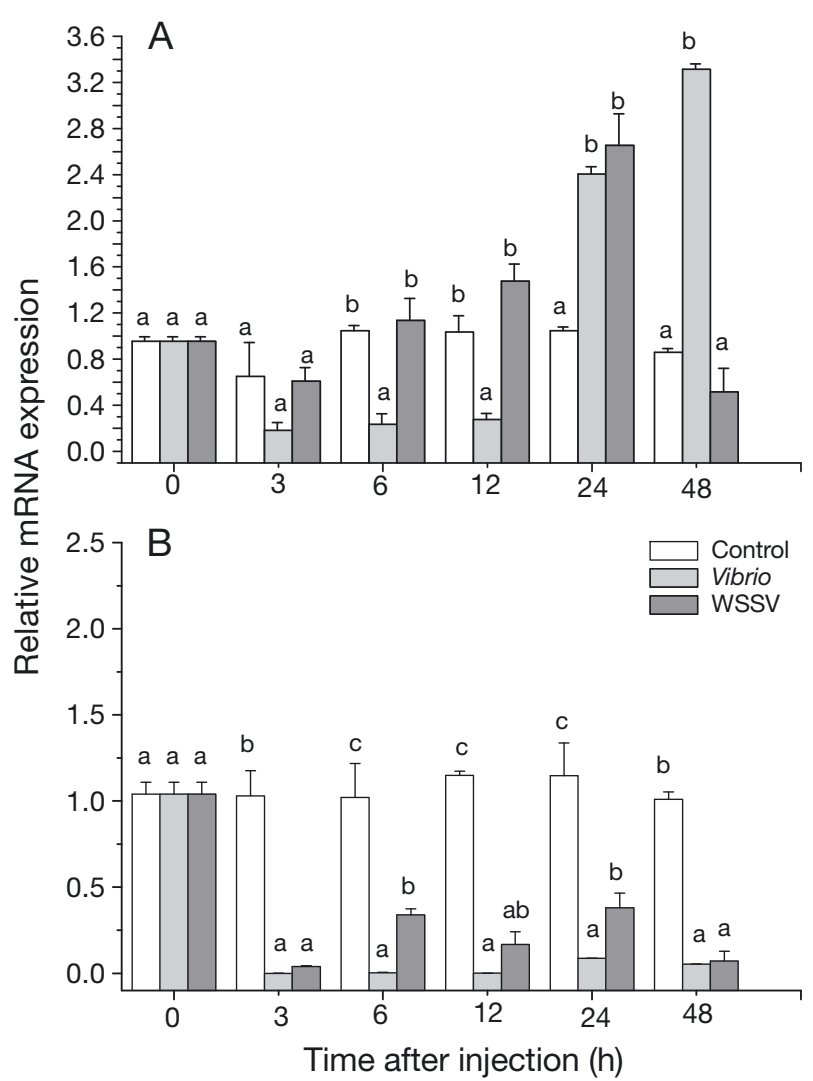

Fig. 5. Litopenaeus vannamei. Mean $( \pm \mathrm{SE})$ lectin expression in (A) hemocytes and (B) the hepatopancreas in response to Vibrio parahaemolyticus and WSSV by real-time RT-PCR at 0 , $3,6,12,24$ and $48 \mathrm{~h}$ post-injection. Different letters indicate significant differences $(p<0.05)$ among treatments at the same time point post-injection

increase after injection with bacteria and virus, with a peak value 66.59 times higher than that of the control group at $3 \mathrm{~h}(\mathrm{p}<0.05)$ after WSSV injection (Fig. 7A). In the hepatopancreas, the level of lysozyme transcripts decreased from 3 to $12 \mathrm{~h}$ post-injection with $V$. parahaemolyticus, and then it began to increase and reached its peak at $48 \mathrm{~h}$ post-injection, with a value 7.24 times as high as that of the control group. However, lysozyme expression increased and reached a peak value at $12 \mathrm{~h}$ after WSSV injection, and then it gradually recovered to the control value at $48 \mathrm{~h}$ (Fig. 7B).

Expression profiles of the C-MnSOD gene in hemocytes and the hepatopancreas after injection are shown in Fig. 8. In hemocytes, C-MnSOD expression significantly increased at 24 and $48 \mathrm{~h}$ after Vibrio parahaemolyticus injection $(\mathrm{p}<0.05)$, with a peak value 17 times higher than that of the control group at $24 \mathrm{~h}$. However, C-MnSOD expression sharply increased at $3 \mathrm{~h}$ and then dramatically decreased from 6 to $48 \mathrm{~h}$ post-injection with WSSV $(p<0.05)$. Increased expression of C-

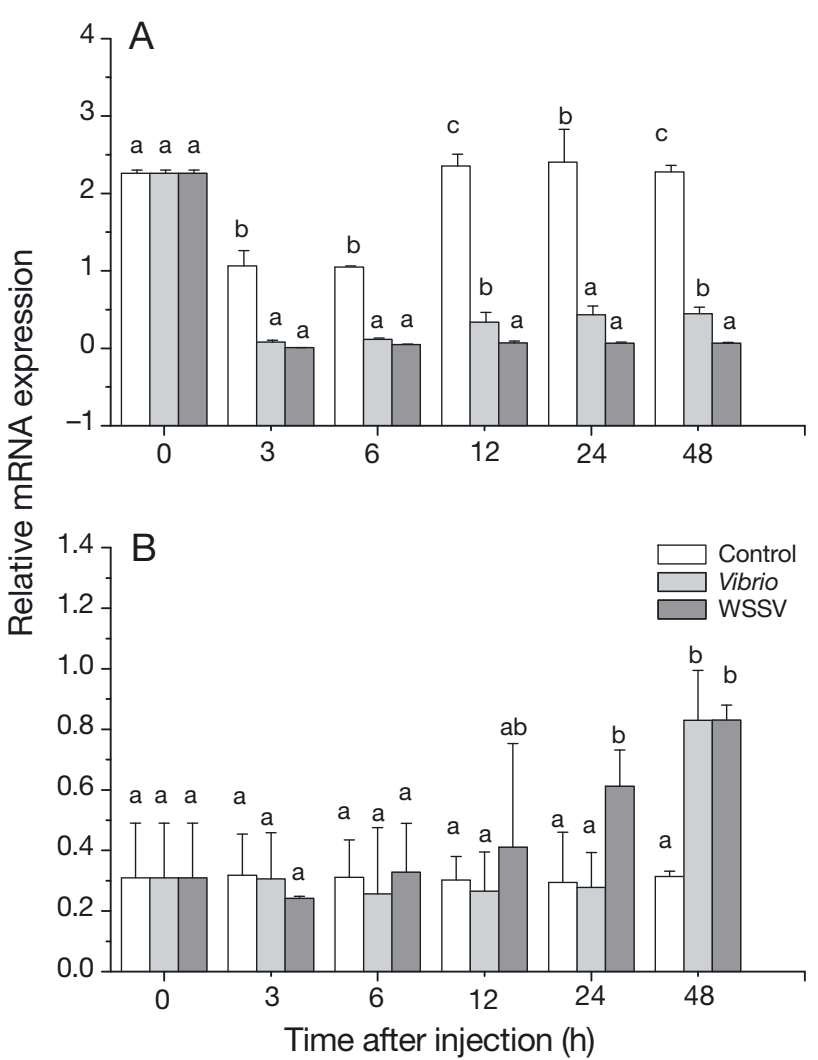

Fig. 6. Litopenaeus vannamei. Mean $( \pm \mathrm{SE})$ prophenoloxidase (proPO) expression in (A) hemocytes and (B) the hepatopancreas in response to Vibrio parahaemolyticus and WSSV by real-time RT-PCR at $0,3,6,12,24$ and $48 \mathrm{~h}$ post-injection. Different letters indicate significant differences $(p<0.05)$ among treatments at the same time point post-injection

MnSOD was also found in the hepatopancreas. C-MnSOD transcript levels began to increase at $3 \mathrm{~h}$ after injection with $V$. parahaemolyticus, peaked at $6 \mathrm{~h}$ and then showed a fluctuating recovery but still maintained a high level at $48 \mathrm{~h}$ post-injection. After WSSV injection, C-MnSOD transcript levels only increased at $6 \mathrm{~h}(\mathrm{p}<$ $0.05)$, then quickly returned to the control level.

Expression profiles of the CAT gene in hemocytes and the hepatopancreas after Vibrio parahaemolyticus and WSSV injection are shown in Fig. 9. In hemocytes, CAT transcripts showed a fluctuating increase from $3 \mathrm{~h}$ after $V$. parahaemolyticus injection, and high levels were observed at 24 and $48 \mathrm{~h}(\mathrm{p}<0.05)$. However, the expression of CAT began to increase at $3 \mathrm{~h}$ and reached a peak value at $24 \mathrm{~h}(\mathrm{p}<0.05)$ after WSSV injection (Fig. 9A). In the hepatopancreas, CAT expression increased significantly from 3 to $48 \mathrm{~h}$ postinjection $(\mathrm{p}<0.05)$ with $V$. parahaemolyticus. It also showed a significant increase post-injection with WSSV, with a peak value 16 times as high as that of the control group at $6 \mathrm{~h}(\mathrm{p}<0.05)$ (Fig. 9B). 


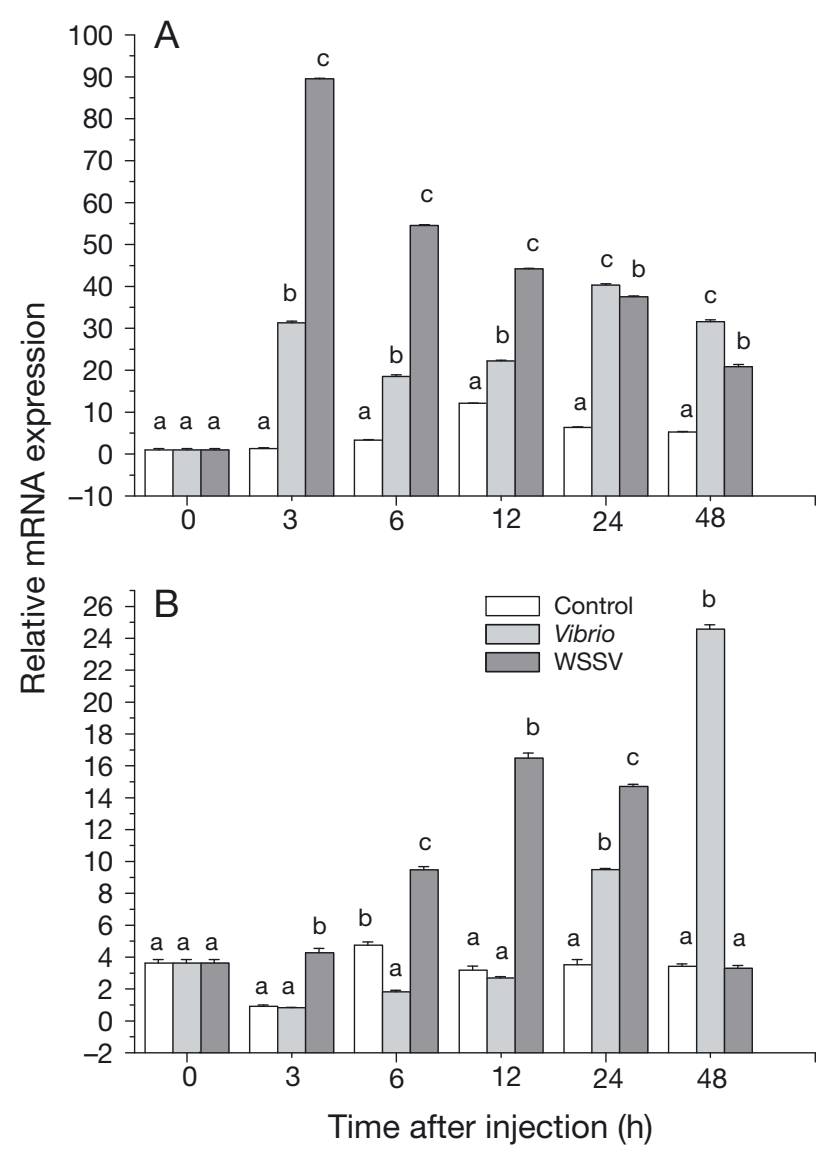

Fig. 7. Litopenaeus vannamei. Mean $( \pm \mathrm{SE})$ lysozyme expression in (A) hemocytes and (B) the hepatopancreas in response to Vibrio parahaemolyticus and WSSV by real-time RT-PCR at $0,3,6,12,24$ and $48 \mathrm{~h}$ post-injection. Different letters indicate significant differences $(p<0.05)$ among treatments at the same time point post-injection

\section{DISCUSSION}

Vibrio parahaemolyticus and WSSV are the main pathogens of shrimp. The present study showed that the mortality of $V$. parahaemolyticus- and WSSVinfected shrimp was significantly higher than that of the control group $(p<0.05)$. Simultaneously, both pathogens were detected in the shrimp, and the increase in the number of pathogens over time revealed that the significant high mortality was due to the replication of the pathogens (Fig. 1, Table 2).

To a certain extent, the THCs reflect the immune response status of the shrimp. The present study demonstrated that THC values decreased after shrimp were injected with Vibrio parahaemolyticus (Fig. 2). This finding is similar to that of another study on Pacific white shrimp Litopenaeus vannamei, which suggested that the variation in hemocytes might be associated with their migration to the injection site for

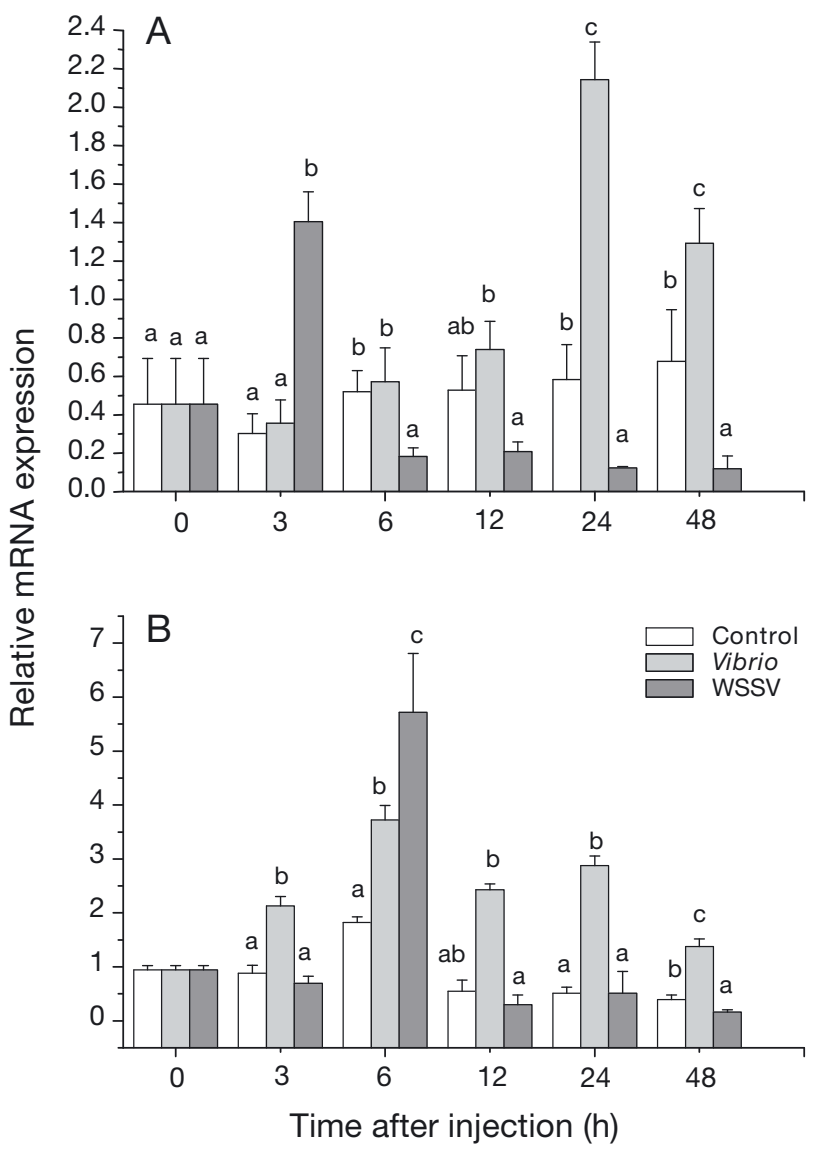

Fig. 8. Litopenaeus vannamei. Mean $( \pm \mathrm{SE})$ cytosolic manganese superoxide dismutase (C-MnSOD) expression in (A) hemocytes and (B) the hepatopancreas in response to Vibrio parahaemolyticus and WSSV by real-time RT-PCR at $0,3,6$, 12,24 and $48 \mathrm{~h}$ post-injection. Different letters indicate significant differences $(p<0.05)$ among treatments at the same time point post-injection

phagocytosis and aggregation of cells in a defense response (Chiu et al. 2007). THCs also dropped rapidly after challenge with WSSV during our experiment (Fig. 2). Simultaneously, our results showed that the proliferation of $V$. parahaemolyticus and WSSV increased dramatically and was time-dependent. Similarly, previous studies have also shown that the THC of L. vannamei decreased significantly after infection with virus (Ai et al. 2008, Yeh et al. 2009). The observed decrease in THCs may, therefore, result from the shrimp defense mechanisms which follow bacterial or viral infection, and might be due to hemocyte lysis, cell recruitment towards infected tissues, nodule formation or interference with hematopoiesis (Martin et al. 1998). The increase in THC after saline injection could be a reaction to tissue injury (Smith \& Söderhäll 1986, Lorenzon et al. 1999).

C-type lectins are involved in the activation of proPO, antibacterial activation, encapsulation and phagocyto- 


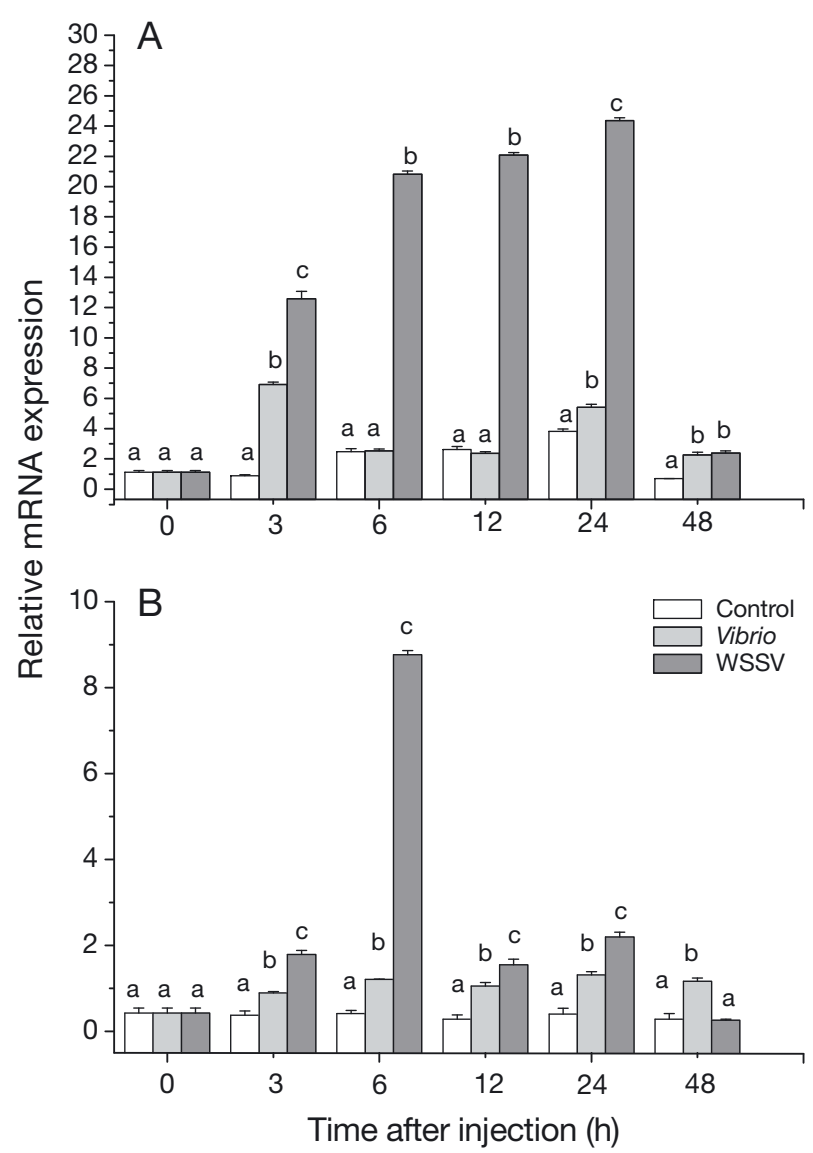

Fig. 9. Litopenaeus vannamei. Mean $( \pm \mathrm{SE})$ catalase expression in (A) hemocytes and (B) hepatopancreas in response to Vibrio parahaemolyticus and WSSV by real-time RT-PCR at 0 , $3,6,12,24$ and $48 \mathrm{~h}$ post-injection. Different letters indicate significant differences $(p<0.05)$ among treatments at the same time point post-injection

sis (Yu et al. 1999, Kaneko et al. 2002, Schroder et al. 2003, Yu \& Kanost 2004), and many other various biological responses in invertebrates. In the present study, the variation in C-type lectin gene expression in hemocytes and the hepatopancreas after pathogen infection was detected by real-time RT-PCR (Fig. 5). The results showed that the lectin expression was significantly higher than that in the control group at $24 \mathrm{~h}$ post-injection with bacteria or WSSV, similar to those of a previous study in which the expression of a putative Ctype lectin gene increased in Chinese shrimp after the injection of mixed inactive bacteria (Liu et al. 2007). Other research has shown that lectin transcripts are upregulated in shrimp hemocytes in response to WSSV infection (He et al. 2005, Liu et al. 2007), suggesting that more lectin needs to be synthesized and might be used for binding or defending against foreign bacteria or virus in hemocytes. However, lectin expression showed sharp down-regulation in the hepatopancreas after injection with Vibrio parahaemolyticus and
WSSV. Similar results were found in Litopenaeus vannamei and Fenneropenaeus chinensis hepatopancreas after WSSV challenge (Ma et al. 2007, Sun et al. 2008), which may have been due to lectin transcripts in the hepatopancreas being seriously damaged or inhibited by pathogen infection.

Recently, an interesting connection between lectins and the proPO-activating system in insects was reported. In our experiments, both Vibrio parahaemolyticus and WSSV were able to significantly inhibit proPO transcripts and $\mathrm{PO}$ activity in hemocytes (Figs. 6A \& 3A), which is consistent with previous studies where gene expression of proPO in lobster Homarus americanus and Litopenaeus vannamei hemocytes could be significantly inhibited by lipopolysaccharide (LPS) and WSSV (Hauton et al. 2005, Ai et al. 2008). In this experiment, PO activity in the hepatopancreas was also significantly inhibited by injection with $V$. parahaemolyticus and WSSV (Fig. 3B). However, it increased significantly at $6 \mathrm{~h}$ after $V$. parahaemolyticus injection and at $3 \mathrm{~h}$ after WSSV injection, suggesting that the hepatopancreas may play an important role in proPO synthesis or active PO release. These results were not consistent with previous studies in which PO activity was enhanced by components of microorganism cell walls, such as LPS and $\beta-1,3$ glucans (Perazzolo \& Barracco 1997, Hauton et al. 2005), suggesting that the regulation of proPO and active PO may be non-synchronous, and that PO might respond more quickly at the protein level than that at the gene level. More interestingly, proPO transcripts showed a significant increase in the hepatopancreas at $48 \mathrm{~h}$ after injection (Fig. 6B), suggesting that the transcription of proPO in the hepatopancreas could be induced by $V$. parahaemolyticus and WSSV. These results indicate that the immune response of the proPO system to different pathogens is not immediate, and support the proposal that proPO activation is mainly based on activation of a serine proteinase from an inactive form to an active form and not on an increase in gene expression levels of proPO (Sritunyalucksana et al. 1999). PO is the terminal enzyme of the proPO system, and the proPO activating system of the penaeid shrimp is associated with many factors (Cerenius et al. 2008), the detailed mechanisms of which need to be further studied.

Söderhäll \& Cerenius (1998) have demonstrated that there is a link between the shrimp proPO activation system and the release of anti-microorganism proteins, among which lysozyme plays an important role in innate immunity. Our study shows that lysozyme transcript levels are increased in both hemocytes and the hepatopancreas after immune challenge (Fig. 7), suggesting that the expression of lysozyme can be induced by Vibrio parahaemolyticus and WSSV, corresponding 
to a previous study suggesting that lysozyme might have a broad anti-bacterial spectrum (Schroder et al. 2003). This latter study also reported that Litopenaeus vannamei lysozyme is mainly expressed in the hepatopancreas and could be induced after bacteria and virus infection.

ROI and ROS are produced during normal aerobic metabolism and increase in physiological conditions that result in oxidative stress and during defense reactions. ROI and ROS are then rapidly eliminated by antioxidant enzymes, which may participate in the production of reactive oxygen compounds used in the destruction of engulfed or encapsulated parasites (Campa-Córdova et al. 2002). As a result, respiratory bursts in hemocytes, and SOD and CAT expression have been widely used to evaluate the defensive ability of shrimp against pathogens (Campa-Córdova et al. 2002). In this study, a significant increase in superoxide anion production in shrimp was found post-injection with Vibrio parahaemolyticus and WSSV (Fig. 4). This indicates that the ROS system plays an important role in shrimp defense against foreign pathogens, which is in agreement with the previous report of Campa-Córdova et al. (2002). Furthermore, our results demonstrate that ROS increased significantly during the early response after WSSV stimulation, suggesting that it may play an important role in this early response to virus infection in shrimp. The transcript levels of CMnSOD and CAT also increased in both hemocytes and the hepatopancreas after $V$. parahaemolyticus and WSSV injection (Figs. 8 \& 9). These results indicate that more anti-oxidant enzymes needed to be synthesized to balance the ROS system, and both ROS and anti-oxidant enzymes might play an important role in shrimp defense against foreign pathogens, corresponding with other reports of shrimp after bacteria and WSSV infection (Cheng et al. 2006, GómezAnduro et al. 2006). The down-regulation of CMnSOD in the later stage post-injection with WSSV might be due to the shrimp immune response being destroyed by WSSV. This is consistent with previous studies which showed that after the injection of WSSV, expression of C-MnSOD increased in the early stage and then decreased in the hemocytes of some shrimp species (Gómez-Anduro et al. 2002, Mathew et al. 2007, Sarathi et al. 2007). C-MnSOD expression peaked earlier in hemocytes than in the hepatopancreas after WSSV injection. This result is consistent with the superoxide anion production, which was very high at 3 and $6 \mathrm{~h}$ after injection, suggesting that hemocytes play a more direct role and the enzymes need be released from the hepatopancreas in response to viral infection. Moreover, C-MnSOD might play a more important role during bacterial infection in shrimp and CAT might be more significant during viral infection.
In conclusion, we evaluated the immune response of the shrimp Litopenaeus vannamei to bacterial and viral infection by examining the immune factors that participated in the immune recognition process, the proPO activating system, the antimicrobial peptide system and the active oxygen defense system, on different expression levels. The results suggest that the shrimp mortality rate increased with pathogen proliferation, and the activity of lectin, lysozyme and the ROS system showed a more dramatic increase than that of the proPO system after Vibrio parahaemolyticus and WSSV infection. The intensity of the immune response was closely related with the types of pathogen and was time-dependent. More importantly, the hepatopancreas also played a significant role in the shrimp immune response.

Acknowledgements. This research was supported by the Major State Basic Research Development Program of China (973 program, 2006CB101804), the National Natural Science Foundation of China (30671605), and the Program for New Century Excellent Talents in Fujian Province University.

\section{LITERATURE CITED}

Ai HS, Huang YC, Li SD, Weng SP, Yu XQ, He JG (2008) Characterization of a prophenoloxidase from hemocytes of the shrimp Litopenaeus vannamei that is down-regulated by white spot syndrome virus. Fish Shellfish Immunol 25: 28-39

Bradford MM (1976) A rapid and sensitive method for the quantitation of microgram quantities of protein using the principle of protein dye binding. Anal Biochem 72: $248-254$

Campa-Córdova AI, Hernández-Saavedra NY, De Philippis R, Ascencio F (2002) Generation of superoxide anion and SOD activity in haemocytes and muscle of American white shrimp (Litopenaeus vannamei) as a response to $\beta$-glucan and sulphated polysaccharide. Fish Shellfish Immunol 12: 353-366

> Cerenius L, Lee BL, Söderhäll K (2008) The proPO-system: pros and cons for its role in invertebrate immunity. Trends Immunol 29:263-271

Chang PS, Chen HC, Wand YC (1998) Detection of white spot syndrome associated baculovirus WSBV in experimentally infected wild shrimps crabs and lobsters by in situ hybridization. Aquaculture 164:233-242

Cheng W, Tung YH, Liu CH, Chen JC (2006) Molecular cloning and characterization of cytosolic manganese superoxide dismutase (cytMn-SOD) from the giant freshwater prawn Macrobrachium rosenbergii. Fish Shellfish Immunol 20:438-449

Chiu CH, Guu YK, Liu CH, Pan TM, Cheng W (2007) Immune responses and gene expression in white shrimp, Litopenaeus vannamei, induced by Lactobacillus plantarum. Fish Shellfish Immunol 23:364-377

> Devasagayam TP, Tilak JC, Boloor KK, Sane KS, Ghaskadbi SS, Lele RD (2004) Free radicals and antioxidants in human health: current status and future prospects. J Assoc Physicians India 52:794-804 
Gómez-Anduro GA, Barillas-Mury CV, Peregrino-Uriarte AB, Gupta L, Gollas-Galván T, Hernández-López J, YepizPlascencia G (2006) The cytosolic manganese superoxide dismutase from the shrimp Litopenaeus vannamei: molecular cloning and expression. Dev Comp Immunol 30: 893-900

> Hauton C, Hammond JA, Smith VJ (2005) Real-time PCR quantification of the in vitro effects of crustacean immunostimulants on gene expression in lobster (Homarus gammarus) granular haemocytes. Dev Comp Immunol 29: 33-42

$>$ He N, Qin Q, Xu X (2005) Differential profile of genes expressed in haemocytes of white spot syndrome virusresistant shrimp (Penaeus japonicus) by combining suppression subtractive hybridization and differential hybridization. Antiviral Res 66:39-45

Hikima S, Hikima J, Rojtinnakorn J, Hirono I, Aoki T (2003) Characterization and function of kuruma shrimp lysozyme possessing lytic activity against Vibrio species. Gene 316: 187-195

> Holmblad T, Söderhäll K (1999) Cell adhesion molecules and antioxidative enzymes in a crustacean, possible role in immunity. Aquaculture 172:111-123

Janeway CA Jr, Medzhitov R (2002) Innate immune recognition. Annu Rev Immunol 20:197-216

Ji PF, Yao CL, Wang ZY (2009) Immune response and gene expression in shrimp (Litopenaeus vannamei) hemocytes and hepatopancreas against some pathogen-associated molecular patterns. Fish Shellfish Immunol 27:563-570

Jollès P, Jollès J (1984) What is new in lysozyme research? Always a model system, today as yesterday. Mol Cell Biochem 63:165-189

Kaneko H, Inoue R, Teramoto T, Morimoto W, Isogai K, Kasahara K, Kondo N (2002) Detection of the genes induced in activated lymphocytes by modified differential display. J Investig Allergol Clin Immunol 12:86-90

Kim YB, Okuda J, Matsumoto C, Takahashi N, Hashimoto S, Nishibuchi M (1999) Identification of Vibro parahaemolyticus strains at species level by PCR targeted to the toxR gene. J Clin Microbio 37:1173-1177

La Peyre JF, Chu FLE (1990) Blue crab haemocytes: a preliminary study. In: Perkins F, Cheng TC (eds) Pathology in marine science. Proc 3rd Int Colloq Path Mar Aquac, Gloucester Point, VA, USA, 2-6 October 1998. Academic Press, San Diego, CA, p 533-538

Lightner DM, Redman RM (1998) Strategies for the control of viral diseases of shrimp in the Americas. Fish Pathol 33: 165-180

Liu YC, Li FH, Dong B, Wang B and others (2007) Molecular cloning, characterization and expression analysis of a putative C-type lectin (Fclectin) gene in Chinese shrimp Fenneropenaeus chinensis. Mol Immunol 44:598-607

Livak KJ, Schmittgen TD (2001) Analysis of relative gene expression data using real-time quantitative PCR and the $2\left(^{-\Delta \Delta C \mathrm{~T}}\right)$ method. Methods 25:402-408

Loker ES, Adema CM, Zhang SM, Kepler TB (2004) Invertebrate immune systems - not homogeneous, not simple, not well understood. Immunol Rev 198:10-24

Lorenzon S, De Guarrini S, Smith VJ, Ferrero EA (1999) Effects of LPS injection on circulating haemocytes in crustaceans in vivo. Fish Shellfish Immunol 9:31-50

Ma TH, Tiu SH, He JG, Chan SM (2007) Molecular cloning of a C-type lectin (LvLT) from the shrimp Litopenaeus vannamei: early gene down-regulation after WSSV infection. Fish Shellfish Immunol 23:430-437

> Martin GG, Kay J, Poole D, Poole C (1998) In vitro nodule formation in the ridgeback prawn, Sycionia ingentis, and the
American lobster, Homarus americanus. Invertebr Biol 117:155-168

Mathew S, Kumar KA, Anandan R, Nair PGV, Devadasan K (2007) Changes in tissue defence system in white spot syndrome virus (WSSV) infected Penaeus monodon. Comp Biochem Physiol C145:315-320

Muñoz M, Cedeño R, Rodriguez J, van der Knaap WPW, Mialhe E, Bachère E (2000) Measurement of reactive oxygen intermediate production in haemocytes of the penaeid shrimp (Penaeus vannamei). Aquaculture 191:89-107

> Okumura T (2007) Effects of lipopolysaccharide on gene expression of antimicrobial peptides (penaeidins and crustin), serine proteinase and prophenoloxidase in haemocytes of the Pacific white shrimp, Litopenaeus vannamei. Fish Shellfish Immunol 22:68-76

> Perazzolo LM, Barracco MA (1997) The prophenoloxidase activating system of the shrimp Penaeus paulensis and associated factors. Dev Comp Immunol 21:385-395

Sarathi M, Ahmed VPI, Venkatesan C, Balasubramanian G, Prabavathy J, Sahul Hameed AS (2007) Comparative study on immune response of Fenneropenaeus indicus to Vibrio alginolyticus and white spot syndrome virus. Aquaculture 271:8-20

Schroder HC, Ushijima H, Krasko A, Gamulin V and others (2003) Emergence and disappearance of an immune molecule, an antimicrobial lectin, in basal metazoa. A tachylectin-related protein in the sponge Suberites domuncula. J Biol Chem 278:32810-32817

Smith VJ, Söderhäll K (1986) Cellular immune mechanisms in the Crustacea. Symp Zool Soc Lond 56:59-79

Smith VJ, Söderhäll K (1991) A comparison of phenoloxidase activity in the blood of marine invertebrates. Dev Comp Immunol 15:251-261

Söderhäll K, Cerenius L (1998) Role of the prophenoloxidaseactivating system in invertebrate immunity. Curr Opin Immunol 10:23-28

Söderhäll K, Unestam T (1979) Activation of serum prophenoloxidase in arthropod immunity. The specificity of cell wall glucan and activation by purified fungal glycoproteins of crayfish phenoloxidase. Can J Microbiol 25: 406-414

Sritunyalucksana K, Söderhäll K (2000) The proPO and clotting system in crustaceans. Aquaculture 191:53-69

Sritunyalucksana K, Cerenius L, Söderhäll K (1999) Molecular cloning and characterization of prophenoloxidase in the black tiger shrimp, Penaeus monodon. Dev Comp Immunol 23:179-186

Sun PS, Soderlund M, Venzon NC Jr, Ye D, Lu Y (2007) Isolation and characterization of two actins of the Pacific white shrimp, Litopenaeus vannamei. Mar Biol 151:2145-2151

Sun YD, Fu LD, Jia YP, Du XJ and others (2008) A hepatopancreas-specific C-type lectin from the Chinese shrimp Fenneropenaeus chinensis exhibits antimicrobial activity. Mol Immunol 45:348-361

Sung HH, Hsu SF, Chen CK, Ting YY, Chao WL (2001) Relationships between disease outbreaks in cultured tiger shrimp (Penaeus monodon) and the composition of Vibrio communities in pond water and shrimp hepatopancreas during cultivation. Aquaculture 192:101-110

Tavares-Sánchez OL, Gómez-Anduro GA, Felipe-Ortega X, Islas-Osuna MA, Sotelo-Mundo RR, Barillas-Mury C, Yepiz-Plascencia G (2004) Catalase from the white shrimp Penaeus (Litopenaeus) vannamei: molecular cloning and protein detection. Comp Biochem Physiol B Biochem Mol Bio 138:331-337

> Vargas-Albores F, Guzman MA, Ochoa JL (1998) Influence of temperature and salinity on the yellowleg shrimp, 
Penaeus californiensis Holmes, prophenoloxidase system. Aquacult Res 29:549-553

Wang YC, Chang PS, Chen HY (2007) Tissue expressions of nine genes important to immune defence of the Pacific white shrimp Litopenaeus vannamei. Fish Shellfish Immunol 23:11661-11677

Xu J, Han F, Zhang X (2007) Silencing shrimp white spot syndrome virus (WSSV) genes by siRNA. Antiviral Res 73: 126-131

Yang F, Wang W, Chen RZ, Xu X (1997) A simple and efficient method for purification of prawn baculovirus DNA. J Virol Methods 67:1-4

Yao CL, Wang AL, Wang ZY, Wang WN, Sun RY (2004) Purification and partial characterization of Mn superoxide dismutase from muscle tissue of the shrimp, Macrobrachium nipponense. Aquaculture 241:621-631

Yao CL, Wu CG, Xiang JH, Dong B (2005) Molecular cloning and response to laminarin stimulation of arginine kinase in haemolymph in Chinese shrimp, Fenneropenaeus chinensis. Fish Shellfish Immunol 19:317-329

Yao CL, Wang AL, Wang ZY, Wang WN, Sun RY (2007) Purification and partial characterization of $\mathrm{Cu}, \mathrm{Zn}$ superoxide dismutase from haemolymph of oriental river shrimp, Macrobrachium nipponense. Aquaculture 270:559-565

Yao CL, Wu CG, Xiang JH, Li F, Wang ZY, Han XZ (2008) The lysosome and lysozyme response in Chinese shrimp

Editorial responsibility: Donald Evans, Athens, Georgia, USA
Fenneropenaeus chinensis to Vibrio anguillarum and laminarin stimulation. J Exp Mar Biol Ecol 363:124-129

Yao CL, Ji PF, Kong P, Wang ZY, Xiang JH (2009) Arginine kinase from Litopenaeus vannamei: cloning, expression, enzymatic properties and interactive pathway. Fish Shellfish Immunol 26:553-558

Yao CL, Ji PF, Wang ZY, Li F, Xiang JH (2010) Molecular cloning and expression of NOS in shrimp, Litopenaeus vannamei. Fish Shellfish Immunol 28:453-460

Yeh SP, Chen YN, Hsieh SL, Cheng W, Liu CH (2009) Immune response of white shrimp, Litopenaeus vannamei, after a concurrent infection with white spot syndrome virus and infectious hypodermal and hematopoietic necrosis virus. Fish Shellfish Immunol 26:582-588

Yu XQ, Kanost MR (2004) Immulectin-2, a pattern recognition receptor that stimulates hemocyte encapsulation and melanization in the tobacco hornworm, Manduca sexta. Dev Comp Immunol 28:891-900

Yu XQ, Gan H, Kanost MR (1999) Immulectin, an inducible Ctype lectin from an insect, Manduca sexta, stimulates activation of plasma prophenol oxidase. Insect Biochem Mol Biol 29:585-597

Zhao J, Song L, Li C, Zou H, Ni D, Wang W, Xu W (2007) Molecular cloning of an invertebrate goose-type lysozyme gene from Chlamys farreri, and lytic activity of the recombinant protein. Mol Immunol 44:1198-1208

Submitted: December 10, 2010; Accepted: May 16, 2011

Proofs received from author(s): July 8, 2011 